\title{
Pola Tabligh Ustadz Cinta Pemuda di Kalangan Remaja Masjid Agung Kota Sukabumi
}

\author{
Rima Angelia ${ }^{1 *}$, Asep Muhyiddin ${ }^{2}, \&$ Tata Sukayat ${ }^{1}$ \\ 'Jurusan Komunikasi dan Penyiaran Islam, Fakultas Dakwah dan Komunikasi, \\ UIN Sunan Gunung Djati, Bandung \\ 2Jurusan Manajemen Dakwah, Fakultas Dakwah dan Komunikasi, \\ UIN Sunan Gunung Djati, Bandung \\ *Email : rimaangelia14@gmail.com
}

\begin{abstract}
This study aims to find out and describe the Tabligh Pattern of Ustadz Cinta, which includes concepts, methods, media, and the content of the messages discussed in the Mabbbah Assembly study in the Great Mosque of Sukabumi City. The method used is descriptive method, the type of data used in this study is a type of qualitative data, data collection techniques using observation techniques, interview techniques, and using documentation techniques. The results can be seen that the tabligh pattern used by the religious teacher in the Mababbah Assembly study is four, namely: concepts, media, message content, and methods used. the concept can provide new innovations in conveying tabligh Khitobah, in terms of the content of the message which has the theme of love, the methods used include lectures, discussion / question and answer, and muhasabah, the media uses modern tools that is using laptops, infokus, pulpit, and mic.
\end{abstract}

Keywords: tabligh; khitabah; majelis mahabbah

\begin{abstract}
ABSTRAK
Penelitian ini bertujuan untuk mengetahui dan menggambarkan Pola Tabligh Ustadz Cinta, yang meliputi konsep, metode, media, dan isi pesan yang di bahas dalam kajian Majelis Mahbbah di Masjid Agung Kota Sukabumi. Metode yang dipakai adalah metode deskriptif, Jenis data yang digunakan dalam penelitian ini adalah jenis data kualitatif, teknik pengumpulan data menggunakan teknik observasi, teknik wawancara, dan menggunakan teknik dokumentasi. Hasilnya dapat diketahui bahwa pola tabligh yang dipakai oleh ustadz cinta dalam kajian Majelis Mahabbah ada empat, yaitu: konsep, media, isi pesan, dan metode yang digunakan. konsep dapat memberikan inovasi baru dalam menyampaikan tabligh khitobah, dari segi isi pesannya yang meimiliki tema tentang cinta, metode yang digunakan diantaranya ceramah, diskusi/tanya jawab, dan muhasabah, medianya menggunakan alat yang modern yaitu dengan menggunakan laptop, infokus, mimbar, dan mic.
\end{abstract}

Kata Kunci : tabligh; khitabah; majelis mahabbah 


\section{PENDAHULUAN}

Tabligh adalah penyampaian pesan ajaran islam kepada masyarakat luas, baik secara lisan, tulisan, dan pekerjaan (i'lam). Orang yang menyampaikan pesan disebut mubaligh, penerimanya disebut muballagh, medianya disebut washilah attabligh dan isi pesannya disebut maudhu At-tabligh.

Dalam perkembangan ilmu dakwah, tabligh diartikan lebih spesifik dan menjadi salah satu bentuk dakwah diantara bentuk-bentuk dakwah yang lain yang secara keilmuan dapat dibedakan walau dalam tataran praktis merupakan satu kesatuan. Setiap kegiatan tabligh akan dikatakan sukses ketika seorang mubaligh memiliki pola tabligh yang bagus dan baik.

Pada kepentingan retorika, seorang pembicara dapat mempergunakan 4 pola komunikasi, yakni : berbicara langsung apa yang dipikirkan (impromptu ramark), membaca naskah (reading from manu script), menghapal (memorizing the speech), memaparkan dengan menggunakan catatan garis besarnya (delivering extemporaneously)

Pola komunikasi disesuaikan dengan kondisi anggota dan komunikan yang ada saat berinteraksi dengan lingkungannya. Pola ini apabila dihubungkan dengan pigur komunikator, pesan dan media (tertulis, audio, video) akan menjadi suatu rangkaian yang beragam dan berkembang . (katz dan kahn, 19966, dalam pace dan faulusez, 2001:-177)

Dalam perspektif ilmu komunikasi mengenai model atau pola adalah sebuah presentasi dari sebuah fenomena tertentu dengan menonjolkan unsurunsur dari fenomena tersebut. Model tersebut menurut Gordon Wiseman Lary barker mempunyai tiga fungsi utama, pertama, untuk melukiskan sebuah proses komunikasi, kedua untuk menunjukan hubungan visual, ketiga untuk membantu dan memperbaiki kemacetan dalam berkomunikasi sehingga tersampaikannya pesan dengan baik. (Mulyana, 2001:123)

Sedangkan tabligh adalah menyampaikan ajaran islam baik melalui media mimbar atau media massa, Pada diri sendiri, keluarga, dan orang lain. Dengan demikian pola tabligh adalah model yang akan digunakan dalam terlaksananya kegiatan tabligh dan terealisasikan dalam berjalannya tablig bagi juru tabligh untuk mempengaruhi mubalagh kearah yang sesuai dengan tujuan tabligh. Dengan begitu pola tabligh sangat berpengaruh terhadap keberhasilah dalam berjalannya kegiatan tabilgh, untuk itu hal ini sangat penting dalam berjalannya kegiatan tabligh. Dengan adanya subuah pola atau model akan mempermudah seorang mubaligh dalam menyampaikan pesan tabligh kepada mubalagh.

Pola tabligh dalam prakteknya tidak lepas pada unsur-unsur tabligh, hal ini selaras dengan teori Harold Lasswell yang menyatakan bahwa jika melihat pada proses komunikasi diantaranya: mubaligh (komunikator), maudhu (isi pesan), wasilah (media), mubalagh (komunikan), pengaruh (efek). 
Karakteristik tabligh dilihat dari segi pesan, media dan metode tabligh. Isi materi yang cenderung lebih meningkatkan minat masyarakat untuk mengikuti acara pengajian, dan metode yang digunakan sesuai dengan perkembangan jaman, begitupun dengan media.

Penerapan teknik tabligh semakin banyak dan beragam, yaitu pada ranah khitobah, kitabah dan I'lam. Dalam bertabligh seorang mubaligh dapat menerapkan pola-pola tabligh yang saat ini sedang berkembang, guna agar mubalagh dapat menerima pesan yang disampaikan oleh seorang mubaligh.

Tabligh tidak dilakukan tanpa sebuah perencanaan, melainkan dipersiapkan secara matang, dari segi materi yang disampaikan, metode yang digunakan, budaya dalam kehidupan mubalagh, maupun media yang dipakainya.

Mubaligh menjadi subjek utama dalam melakukan tabligh. Mubaligh ialah pelaku tabligh yang menyabarluaskan ajaran islam, dilakukan secara langsung ataupun secara tidak langsung. Melakukan upaya perubahan kearah yang lebih baik menurut ajaran islam.

Seorang mubaligh perlu memiliki kepribadian yang bersifat ruhaniah ataupun jasmaniah. Karena seorang mubaligh mempunyai kedudukan yang sangat penting dihadapan masyarakat. Perbuatan dan tingkah laku seorang mubaligh menjadi tolak ukur bagi masyarakatnya.

Perkembangan teknologi dan gaya hidup yang semakin meningkat dapat mempengaruhi psikologis dan sosial masyarakat, sehingga menjadi sebuah tantangan bagi seorang mubaligh dalam menyampaikan ajaran islam kepada masyarakat. Dalam hal ini seorang mubaligh dituntut memiliki kemampuan untuk mengemas pesan-pesan tabligh secara jenaka sehingga dapat merebut simpati dan perhatian khalayak. (Kusnawan, 2004:18) Selain itu seorang mubaligh juga perlu memiliki pola-pola yang bagus untuk bertabligh dalam menghadapi situasi muballagh saat ini.

Tabligh berasal dari kata ballagha-yuballighu-tabliighan, yang artinya menyampaikan. (Munawir 1997:107)

Menurut Dr. Ibrahim Imam dalam al-Ushul al-ilan al-Islamy, yang dikutip oleh enjang AS dalam Dasar-dasar Ilmu Dakwah adalah: " memberikan informasi yang benar, pengetahan yang faktual dan hakikat pasti yang bisa menolong atau membantu manusia untuk membentuk pendapat yang tepat dalam suatu kejadian atau dari berbagai kesulitan. (Enjang 2009:53)

Dari segi sifatnya, tabligh bersifat terus menerus, karena tabligh dijalankan dari mualai nabi Muhammad diangkat sebagai Rasul, sampai menjelang kematian beliau, dan sampai sekarang dilanjutkan oleh para pengikutnya. Hal ini dijelaskan di dalam beberapa firman Allah, yaitu, QS Al-maidah ayat 67:

Wahai Rasul! Sampaikanlah apa yang diturunkan tuhan-Mu kepadamu jika tidak engkau lakukan (apa yang diperintahkan itu) berarti engkau tidak menyampaikan amanat-Nya. Dan Allah memelihara engkau dari (gangguan manusia). Sungguh Allah tidak memberikan petunujuk kepada orang-orang kapir. (Menteri Agama:1997) 
Ayat diatas menunjukan bahwa Allah telah memerintahkan kepada Nabi Muhammad agar melaksanakan tabligh, dan merupakan perintah kepada umatnya. Berkaitan dengan kewajiaban tabligh yang di jelaskan dalam Al-Qur'an terdapat pula hadist Rasulullah Saw yang berkaitan dengan tabligh, antara lain: "Sampaikan apa-apa dari aku, walaupun hanya satu ayat."

Dilihat dari penerapan retorika monologika tabligh terbagi menjadi dua pemahaman, yakni tabligh dengan huruf " $t$ " kecil dan tabligh dalam huruf "T" besar. Tabligh dengan " $t$ " kecil adalah tabligh dalam pengertian etimologi. Dalam pengertian tabligh dengan huruf " $\mathrm{t}$ " kecil ini, ketika seseorang menyampaikan informasi kepada orang lain, baik dalam jumlah nya yang terbatas maupun tak terbatas, maka itu bisa disebut tabligh. Adapun tabligh dengan " $T$ " besar adalah tabligh dalam pengertian terminologi. Dalam pengertian ini tabligh difahami sebagai sebuah usaha dan upaya untuk mendipusikan ajaran islam secara lisan maupun tulisan dengan cara yang langsung atau bermedia demi tersebarnya dan tersyiarnya ajaran Islam, Melalui disebarkan dan disyiarkannya ajaran Islam ini maka kerangka refensi (frame of reference) umat akan disisi oleh ajaran islam yang ditangkapnya dengan jelas. karenanya kerangka pengalaman (field of experience) umatpun adalah ajaran islam yang diperolehnya sebagai trycle down effect (efek rembesan) dari proses itu.

Kegiatan tabligh merupakan sebuah kewajiban bagi setiap orang yang memiliki kemampuan dan ilmu yang luas untuk menyampaikan ajaran islam kepada semua orang, meskipun pada dasarnya kegiatan tabligh tidak semua orang bisa melalukakannya. Dasar atau landasan hukum yang menjadi pijakan dalam bertabligh yaitu Al-Qur'an dan Assunah. Al-Qur'an merupakan wahyu Allah yang menjadi pedoman hidup bagi manusia, untuk itu Al-Qur'an menajdi dasar hukum dalam melaksanakan kegiatan tabligh, begitupun dengan as-sunah, as-sunah merupakan pedoman kedua yang menajdi dasar hukum tabligh.

Tujuan utama tabligh adalah nilai atau hasil akhir yang ingin dicapai atau diperoleh oleh keseluruhan tindakan tabligh. Untuk tercapainya tujuan utama inilah maka semua penyusunan, rencana, dan tindakan tabligh harus ditujukan dan diarahkan. Tujuan utama tabligh sebagaimana telah dirumuskan ketika memberi pengertian tentang tabligh yaitu terwujudnya kebahagiaan dan kesejahtraan hidup di dunia dan di akhirat yang diridhai Allah Swt.

Menurut Abu Zahrah Tabligh disebut juga komunikasi islam, karena unsur komunikasi islam berlandaskan nilai-nilai islam yaitu Al-Qur'an dan sunnah. Maka tabligh adalah sebuah realisasi konsep secara implementatif. Sebagai implementasi dari sebuah konsep, seluruh kebijakan tabligh dan langkahnya tidak lepas dari apa yang digariskan dalam konsep dasar islam. Dengan itu tujuan tabligh tidak lain dari tujuan islam, yaitu transformasi sikap manusia, atau dalam terminologi alQur'an disebutka al-ikhraj min al-zulumat ila al-nur. menurut pakar tafsir Abu Zahrah, al-nur (cahaya) adalah simbol dari karakteristik asal kemanusiaan (fitrah). Karena hidup manusia akan bersinar hanya jika ia secara natural mengikuti karakter asal tersebut. Sebaliknya al-Zulm (kegelapan) adalah simbol yang 
menunjukan kepada situasi penyimpangan manusia pada karakter asalnya.

Tabligh juga bertujuan menciptakan suatu tatanan kehidupan individu dan masyarakat yang aman, damai, dan sejahtera yang dinaungi oleh kebahagiaan baik jasmani maupun rohani dalam pancaran sinar agama Alah dengan mengharap ridha nya.

Aktivitas tabligh dilakukan dengan senantiasa mengharapkan ridha Allah dalam kehidupan yang terus menerus mengabdikan berbagai kebijakan tabligh. Secara sistematis, tujan tabligh adalah: (1) tazkiyatu l-nafs, yaitu membersihkan jiwa masyarakat dari noda-noda syirik dan pengaruh-pengaruh kepercayaan yang menyimpang dari akidah islam. (2) mengembangkan kemampuan baca tulis, yaitu mengembangkan kemampuan dasar masyarakat meliputi kemampuan membaca, menulis, dan memehami makna Al-Qur'an serta sunah nabi Saw. (3) membimbing pengalaman ibadah, yaitu umat islam perlu mendapat bimbingan ibadah sehingga bobot ibadahnya menjadi baik. (4) meningkatkan kesejahteraan yaitu meningkatkan kesejahteraan sosial, ekonomi, dan pendidikan. (Ma'ariif 2010: 80)

Kegiatan tabligh dalam prosesnya akan melibatkan unsur-unsur tabligh yang terbentuk secara sistematik, yaitu antara unsur yang satu dengan unsur yang lain saling berkaitan. Adapaun unsur-unsur tabligh yaitu sebgai berikut: Mubaligh (Subjek tabligh), Mubalagh (objek tabligh), Maudhu (Materi tabligh), Wasilah (Media tabligh), Uslub (Metode tabligh)

pola adalah bentuk atau model (lebih abstrak, suatu set peraturan) yang bisa dipakai untuk membuat atau menghasilkan suatu bagian yang lebih bagus. Menurut Sereno dan Mortensen, pola atau model komunikasi merupakan deskripsi ideal mengenai apa yang dibutuhkan untuk terjadinya komunikasi. Model komunikasi mempresentasikan secara abstrak ciri-ciri penting dan menghilangkan rincian komunikasi yang tidak perlu dalam dunia nyata.

pola tabligh adalah rancangan atau model dalam penyampaian dan pemberitaan tenang ajaran-ajaran islam kepada umat manusia. Pola tabligh sama dengan pola komunikasi, yaitu memberikan data untuk memahami dan mengerti tindakan atau tingkah laku seseorang, kelompok atau organisasi yang muncul.

Ada 3 faktor pembentuk pola komunikasi seseorang, yaitu (1) proses sejarah atau pengalaman masa lalu yang kemudian membentuk kebiasaan-kebiasaan yang menjadi bagian dari kepribadian, (2) kapasitas diri sebagai akibat dari faktor pendidikan, pelatihan serta pengalaman hidup diri seseorang dalam menempuh kehidupan, dan (3) maksud dan tujuan dari aktivitas komunikasi sehingga membawa kepada penyesuaian pesan, metode, dan media yang digunakan. (Ma'ariif, 2010:79)

Pada kepentingan retorika, seorang pembicara dapat mempergunakan 4 pola komunikasi, yakni (1) berbicara langsung apa yang dipikirkan (impromptu ramark), (2) membaca naskah (reading from manu script), (3) menghapal (memorizing the speech), (4) memaparkan dengan menggunakan catatan garis besarnya (delivering extemporaneously)

Pola komunikasi disesuaikan dengan kondisi anggota dan komunikan yang 
ada saat berinteraksi dengan lingkungannya. Pola ini apabila dihubungkan dengan pigur komunikator, pesan dan media (tertulis, audio, video) akan menjadi suatu rangkaian yang beragam dan berkembang. (katz dan kahn, 19966, dalam pace dan faulusez, 2001:-177)

Melakukan tabligh islamiyah perlu rujukan khusus dalam menyampaikan nya, agar penyampaian sesuai dengan yang di perintahkan oleh Allah SWT, yang pertama yang menjadi sumber dalam melakukan tabligh islamiyah ini adalah AlQur'an.

Dalam pandangan Sayyid Qutb, Al-Qur'an merupakan kitab dakwah, yaitu sebagai landasan pertama tentang apa dan bagaimana bertabligh. Disebutkan juga oleh Sukriyadi Sambas, Menurutnya Al-Qur'an adalah kitab tabligh yang merupakan penyampaian Allah. Selain Al-Qur'an, hadist juga sebagai rujukan dalam melakukan kegiatan Tabligh. Hadist menrupakan imformasi tentang sunah nabi.

Diantara sekian banyak penerapa pola tabligh, seorang mubaligh rata-rata dari segi pesan yang disampaikan tidak keluar pada ranah akidah, fiqih, dan akhlak. Namun ada beberapa mubaligh yang menerapkan pola tabligh berbeda, termasuk dari segi pesan. Hal ini terjadi pada ustadz cinta.

Ustadz cinta yang kelahiran sukabumi ini menjadi seorang mubaligh yang berbeda dengan mubaligh lainnya, dalam melakukan tabligh ustadz cinta memiliki pola tabligh yang sangat unik, terutama pada segi pesan yang disampaikannya. Tema dalam menyampaikan pesan tabligh ialah tentang cinta.

Ustadz cinta adalah seorang mubaligh yang kreatif dan inovatif dalam menyampaikan pesan tabligh, beliau berasal dari sukabumi. Beliaupun seorang pimpinan pesatren Biru di Sukabumi, Direktur Mahabbah Traning center, dan pembina majlis mahabbah masjid Agung Sukabumi.

Berawal dari Perjalanan dakwahnya ustadz cinta pada media radio NBS FM dalam acara manajemen cinta, pada tahun 2001, program ini bertahan selama 13 tahun, dan akhirnya mendapatkan respon yang sangat baik, setelah itu ustadz cinta mengadakan pertemuan dengan para pendengar, dan lahirlah sebuah komunitas yaitu KOMUCIN (komunitas cinta), dalam acara ini di buka layanan P3C (pertolongan pertama pada cinta), yaitu layanan konsultasi bagi para pendengar. Setelah berjalan selama 13 tahun akhirnya KOMUCIN diganti menjadi Majelis Mahabbah pada tahun 2013/2014 dan sampai sekarang masih berjalan. Kajian majelis mahabbah menjadi acara kajian rutinan, yang di adakan di Masjid Agung Kota Sukabumi, setiap hari ahad, pukul 16:00-17:30 dan sampai sekarang kajian itu masih di lakukan, para mustaminyapun semakin terus bertambah.

Tema yang mengusung cinta menjadikan seorang ustadz cinta mampu melahirkan para mubalagh yang mencintai majelis ta'lim dan rutin mengikuti pengajian. Dan yang lebih unik sasaran dakwah dalam pengajian ini adalah para remaja. Kemasan isi pesan dan cara penyampaian yang berbedalah yang menjadi sebuah ketertarikan bagi para mubalagh, penyampaian pesan dengan menggunakan silde, infokus, sesekali menampilkan video motivasi. kegiatan ini 
berlangsung selama satu jam setengah, dengan pemaparan materi selama 15 menit lalu disambung dengan konsultasi para mubalagh terhadap isi pesan yang baru saja disampaikan.

Pada acara sesi konsultasi setiap orang mempunyai keberanian yang berbeda-beda, ada yang berani langsung bertanya dihadapan orang banyak, ada juga orang yang tidak bisa mengungkapkan apa yang ia ingin tanyakan ataupun malu untuk mengungkapkannya, untuk masalah mubalagh yang seperti ini konsultasipun bisa dengan menulis dikertas.

Dari pemaran diatas, pola tabligh yang digunakan ustadz cinta sangat bagus untuk dijadikan sebuat model atau contoh untuk ustadz lainnya, dengan itu penerapan pola tabligh ustadz cinta perlu dikaji dan diteliti, agar menjadi pendorong dan motivasi peningkatan dalam bertabligh.

\section{HASIL DAN PEMBAHASAN}

Penelitian ini dilakukan di Masjid Agung Sukabumi yang terletak di jln A. Yani kampung kaum kelurahan Gunung Parang, kecamatan Cikole kota Sukabumi Jawa Barat Kode Pos 43121 pada koordinat 6 55’16” LS dan 106 55’30”BT. Dilihat dari sisi sejarah, Masjid Agung sudah berdiri pada akhir abad ke 19. Hal ini dibuktikan dengan bukti foto atau dokumentasi masjid pada 1890 Masehi. Masjid Agung Sukabumi menjadi satu-satunya masjid yang berdiri ditengah Kota Sukabumi hingga akhir abad 19. Bangunan masjid lainnya baru bermunculan setelah memasuki abad ke 20.

Selama berdiri hingga 2018, Masjid Agung Sukabumi sudah mengalami pemugaran dalam skala besar sebanyak 6 kali. Pelaksanaan pemugaran dilakukan pada tahun 1900, 1936, 1945, 1975, 2004, dan 2012. Peresmian Masjid Agung Sukabumi setelah pemugaran terakhir dilakukan pada 12 Mei 2013 oleh Gubernur Jawa Barat Ahmad Heryawan dan Wali Kota Sukabumi pada saat itu Mokh Mukhlis Abdussyukur.

Bagunan Masjid yang baru ini, di desain oleh pemenang sanyembara desain masjid, yakni arsitek asal Bandung Dedi Sudharmanwan. Saat ini bagun masjid terlihat megah dengan kubah berwarna kuning keemasan. Uniknya, ada ornament senjata khas jawa barat yakni kujang disetiap menara. Hal ini menunjukan perpaduan antara islam dengan budaya lokal.

Kegiatan di Masjid Agung Sukabumi selain tempat ibadah juga sebagai tempat menimba ilmu. Adapun kegiatan-kegiatan atau program yang diadakan di Masjid Agung Kota Sukabumi adalah sebagai berikut: (a) pengajian hari besar islam, (b) pengajian rutinan setiap seminggu sekali. Pengajian diadakan untuk kalangan ibu-ibu dan bapak-bapak, rata-rata dari kalangan menengah keatas. (c) Sholat Jum'at

Melihat program yang diadakan di masjid Agung hanya menyapa kaum manula, sedangkan untuk kaum remaja sangat minim, untuk itu kedatangan sosok seorang mubaligh memiliki program yang sangat bagus dan program ini disajikan untuk kalangan anak muda. Dengan adanya program kajian khusus untuk 
kalangan remaja memiliki dampak positif terhadap masjid, salah satunya yaitu masjid lebih bayak dikunjungi oleh anak-anak remaja.

Kegiatan yang diadakan dimasjid Agung Kota Sukabumi sebagai pelaksana dari semua kegiatan adalah Pemuda Remaja Masjid Agung Kota Sukabumi. Pemuda Remaja Masjid Agung Kota Sukabumi didirikan oleh Wawan dan kawankawan, pada tahun 1983. Dalam dimensi sejarahnya, organisasi ini muncul atas dasar kepeduliaan para remaja untuk membangun dan mengembangkan masjid dari segi kualitasnya.

Pemuda Remaja Masjid sudah berjalan selama 35 tahun sampai sekarang, organisasi ini berkiprah pada masjid untuk ikut serta mengembangkan masjid menjadi lebih baik.

Orang yang terlibat pada organisasi pemuda remaja masjid meliputi dari kisaran umur 16-40 tahun, untuk kepengurusan lebih banyak anak SMA Sederajat. Organisasi ini berada di bawah kepengurusan Masjid Agung Kota Sukabumi, dan tempatnya berada di belakang lantai dua belakang masjid.

Beberapa kajian yang dikelola langsung oleh pemuda remaja masjid ada satu kajian yang bekerja sama dengan Ustadz Cinta. Yaitu kajian Majelis Mhabbah, yang diadakan setiap hari minggu jam 16:00.

Majelis mahabbah merupakan sebuah kajian yang berisikan tentang cinta, baik cinta kepada Allah, kepada Rasulullah, orang tua, ataupun rekan kerja. Kajian majelis Mahabbah diadakan di Masjid Agung Kota Sukabumi.

Majelis mahabbah adalah berasal dari kata bahasa Arab yang berarti majelis adalah perkumpulan yang positif, sedangkan mahabbah adalah cinta, maka majelis mahabbah adalah perkumpulan orang-orang yang mengikuti kajian tentang cinta.

Sejarah menjelaskan bahwa kajian ini berawal pada media radio NBS FM dalam acara manajemen cinta, pada tahun 2001, program ini bertahan selama 13 tahun, dan akhirnya mendapatkan respon yang sangat baik, setelah itu ustadz cinta mengadakan pertemuan dengan para pendengar, dan lahirlah sebuah komunitas yaitu KOMUCIN (komunitas cinta), dalam acara ini di buka layanan P3C (pertolongan pertama pada cinta), yaitu layanan konsultasi bagi para pendengar. Setelah itu komucin diganti dengan majelis mahabbah pada tahun 2013, sampai saat ini majelis mahabbah masih berjalan dengan baik, dan lebih berkembang. Agar acara berjalan dengan lancar, acara kajian majelis mahabbah ini bekerjasama dengan pengurus pemuda remaja masjid. Setelah 5 tahun berjalan dengan lancar, akhirnya kajian majelis mahabbah menjadi program tetap pemuda remaja masjid.

Kosep yang dipakai dalam kajian majelis mahabbah adalah memakai konsep mamajemen cinta, yaitu sebuah konsep yang menghadirkan dalam setiap programnya dikemas dalam bentuk motivasi dan siraman rohani yang disesuaikan dengan kebutuhan, Sehingga kajian ini cocok digunakan untuk umum. Konsep manajemen cinta pada kajian ini lebih pada konsep tazqiyatunnafs, yaitu pembersihan diri.

Materi atau isi pesan yang disampaikan seputar cinta, baik cinta kepada 
Allah, Rasul, orangtua, tetangga, rekan kerja, anak, istri, dan yang lainnya, semua materi yang disampaikan tidak keluar dari cinta.

Mubalagh dalam kajian majelis mahabbah rata-rata diisi oleh pemuda kisaran usia 16 hingga 55 tahun. Bahkan, ketika kajian rutin setiap hari minggu, kajian ini mampu mengajak ratusan mubalagh merapati masjid.

Kajian majelis mahabbah menyuguhkan kajian islam untuk anak muda, meskipun banyak juga kalangan orangtua yang mengikuti kajian ini, dengan tema tentang cinta yang di sesuaikan dengan kedaan zaman saat ini, atau hal-hal yang lagi viral.

Ustadz cinta merupakan mubaligh yang mengisi langsung dalam kajian ini, selain itu ustadz cinta sebagai pembina dari kajian majelis mahabbah. Kajian ini berjalan dengan baik karena semua di persiapkan oleh ustadz cinta, dari mulai konsep, materi, sampai pelaksanaan, meskipun secara teknisi dibantu oleh pengurus remaja masjid.

Kajian majelis mahabbah di adakan di Masjid Agung Kota Sukabumi, kajian ini diadakan setiap hari ahad pada jam 16:00 samapai jam 17:30, sebelum kajian dimulai diawali dengan pembacaan ayat suci Al-Qur'an, oleh panitia. Setelah kajian siap dimulai acara berjalan seperti biasanya di pandu oleh seorang mc dan dilanjutkan ceramah yang diisi oleh ustadz cinta dan di penghujung acara diakhiri oleh muhasabah.

Hasil penelitian ini menemukan pola tabligh ustadz Cinta dalam kajian Majelis Mahabbah di masjid Agung Sukabumi, pola ini meliputi konsep yang dipakai oleh ustadz cinta, materi yang dipakai, media yang digunakan dan metode yang dipakai dalam menyampaikan tablighnya.

\section{Pola Tabligh Ustadz Cinta}

Pola tabligh merupakan rancangan atau model dalam penyampaian dan pemberitaan tentang ajaran-ajaran islam kepada umat manusia. Pemeran utama dalam penyampaian tabligh adalah mubaligh, maka dalam menyampaikan pesan tabligh perlu memiliki langkah langkah dan rancangan yang inovatif dan kreatif, agar pesan tersampaikan dengan baik. Adapun pola tabligh ustadz Cinta yaitu sebagai berikut:

Selain konsep seorang mubaligh juga perlu memiliki keunikan atau pembeda dengan mubaligh lain, hal ini untuk menarik para mubalagh dalam mengikuti acara pengajian. Dalam bertabligh keunikan dapat dilihat dari beberapa unsur tabligh, yaitu pada pesan yang disampaikan, metode yang dipakai dan media yang digunakan.

Dari pemaparan diatas dapat di gambarkan bahwa pola tabligh ustadz Baharsyah Al-Munir yaitu sebagai berikut:

\section{Pola Tabligh Ustad Cinta}

\section{Pola Tabligh Ustad Cinta}

\section{(Ustadz Baharsyah Al- Munir)}




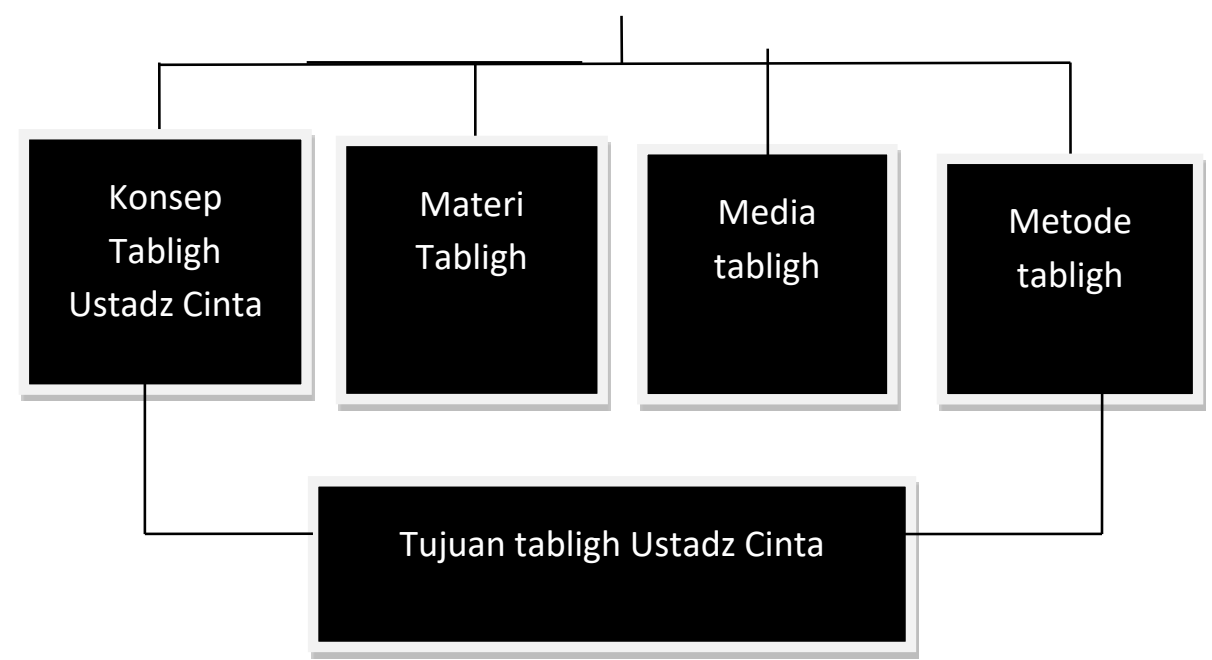

Dari bagan diatas dapat disimpulkan bahwa pola tabligh ustdaz cinta meliputi beberapa unsur, diantaranya:

\section{Konsep Tabligh Unstadz Cinta}

Konsep ialah istilah yang biasa bisa digunakan untuk menggambarkan secara abstrak dari suatu objek untuk menggambarkan untuk tujuan mengklasifikaskan ataupun mengkategorikan peristiwa. Konsep juga dapat menyatukan sejumlah benda seperti gagasan, peristiwa maupun fenomena menjadi sutu kesatuan.

Ustadz cinta dalam tablignya memakai konsep yang bernama nanajemen cinta, konsep ini sama dengan etos kerja berbasis spiritual. Arti dari manajemen cinta itu sendiri diambil dari dua kata yaitu manajemen dan cinta, manajemen mengandung arti proses penggalian, pencarian, pengelolaan, dan pengoptimalan, sedangkan cinta adalah ungkapan hati, pengorbanan, rindu, kasih sayang, maka manajemen cinta adalah sebuah proses untuk menata, mengelola, dan mengoptimalkan potensi diri agar kita dapat menyikapi kejadian apapun dalam hidup kita dengan sikap terbaik kita atas dasar cinta

Konsep mamajemen cinta merupakan konsep yang menghadirkan dalam setiap programnya dikemas dalam bentuk motivasi dan siraman rohani yang disesuaikan dengan kebutuhan. Program-program yang diberikan sangat menarik, inspiratif, inovatif, menyentuh hati, dan memberikan ide-ide serta hal baru yang dapat di aplikasikan dalam kehidupan sehari-hari. Menghadirkan islamic Games yang menyenangkan dan menginspirasi. Setiap simulasi yang diberikan mengandung nilai-nilai berharga dan disertai muhasabah renungan disetiap akhir kegiatan.

Adapun tujuan dari konsep manajemen cinta adalah sebagai berikut: (1) Mengajak masyarakat, terkhusus anak muda untuk mengenal islam melalui 
kegiatan-kegiatan kreatif, (2) Mematangkan intelektual emosional, dan spiritual, (3) Meningkatkan rasa persaudaraan sesama muslim dengan kegiatan islam, kemudian mengenalkan dasar-dasar keislaman kepada anak-anak muda yang masih awam terhadap ajaran islam. (4) Menangkal gerakan-gerakan yang bertujuan untuk merusak moral generasi muda

Konsep manajemen cinta meningkat dengan pesat, konsep ini memakai metode yang sangat kekinian, adapun metode yang dipakainya adalah sebagai berikut: Metode diskusi, Metode ceramah, Metode demontrasi, Metode lomba, Metode simulasi, Metode kreasi, Metode mentoring, Metode praktek, Metode muhasabah, Metode observasi.

\section{Materi Tabligh Ustadz Cinta dalam Kajian Majelis Mahabbah}

Materi tabligh (maudhu at-tabligh) merupakan isi pesan atau materi yang disampaikan seorang mubaligh kepada para mubalagh, pada dasarnya bersumber dari Al-Qur'an dan hadist sebagai sumber utama yang meliputi akidah, muamalah, ibadah dan akhlak. Hal yang harus diketahui bahwa ajaran islam tidak hanya untuk diketahui, tapi bagaimana menanamkan kesadaran yang mendalam agar mampu mengaplikasikan akidah, muamalah, ibadah dan akhlak dalam ucapan, tindakan dalam kehidupan sehari-hari.

Selain itu, dengan adanya perkembangan teknologi dan perubahan zaman, maka materi tabligh (ceramah) perlu dimuati dasar-dasar kehidupan dalam masyarakat yang seutuhnya, yaitu dengan dilandasi faham keislaman. Dengan begitu masyarakat perlu diperkenalkan pola kehidupan yang benar, mengikuti zaman tanpa harus menghilangkan hakikat yang sebenarnya, seperti bagaiman merubah diri menjadi yang lebih baik dan Selain itu pengambilan materi yang disesuaikan dengan masyarakat saat ini.

Begitupun dengan ustadz cinta, dalam menyampaikan ajaran islam, beliau kemas dengan materi seputar cinta, karena hari ini semua orang membutuhkan hal itu, baik anak muda ataupun orang tua. Tujuan dari pengambilan materi tentang cinta ini adalah untuk bisa bagaimana semua orang bisa memanage cinta agar terarah pada cinta kepada Allah, baik pada sesama manusia, orang tua, terhadap pekerjaan, terhadap ibadah, dan sebagainya. (ustadz cinta, 1 Maret 2018, 09:43)

Materi cinta juga mejadi ciri khas dalam bertablighnya, setiap materi tidak lepas dari cinta, setiap minggu ustadz cinta menyampaikan pesan tentang cinta yang di disesuaikan dengan realita saat ini, Meskipun tujuannya pada cinta kepada Allah.

Selain materi tentang cinta, ustadz cinta juga menyampaikan pesan tentang muhasabah, materi ini disampaikan agar lebih memantapkan isi materi yang sudah dibahas, sehingga kajian selama satu jam setengah bisi berpengaruh dalam kehidupan seorang mubalagh. Karena memang dalam kenyataanya seorang mubalagh lebih suka dengan selalu diingatkan untuk menjadi pribadi yang lebih baik lagi.

Adapun beberapa judul materi yang disampaikan oleh ustadz cinta dalam 
kajian rutin majelis mahabbah di masjid agung diantarnya adalah sebagai berikut: (a) OBSESI (obrolan seputar studi islam), kala hati DILANda kekeringan. Kajian tentang materi ini disampaikan pada tanggal 18 february 2018, pada kajian ini tidak hanya diisi dengan ceramah, tapi juga diisi dengan acra parade tilawah, dan pelatihan tahsin klasikal. udul kajian obsesi di sesuaikan dengan realita pada saat itu, pada bulan februari lagi rame-ramenya tentang film dilan, maka ustadz cinta berinisiatif mengambil tema yang menynggung tentang dilan. (2) La tahzan, don't be sad, Allah is with us. Kajian la tahzan dilaksanakan pada tanggal 15 oktober 2017, bertempat di masjid Agung Kota Sukabumi, kajian dilaksanakn selama satu jam setengah. Latar belakang memakai tema ini karena saat ini orang lebih terpuruk dengan keadaannya saat ini, banyak yang tidak menerima kenyataan hidup yang sedang dijalani, maka tema yang diusung adalah La tahzan, jangan bersedih, karena Allah bersama kita. Menginstal kasih sayang, Setiap orang meniginginkan kasih sayang, baik dari orangtua, kakak, adik, teman, atapun seorang pasangan, entah itu suami atau istri, namun yang jadi pertanyaanya apakah kasih sayang ini murni apa tidak, apa landasan kita menyayangi orang-orang sekitar. Banyak orang yang menginginkan utuk disayangi tapi tidak tahu tentang hakikat kasih sayang itu sendiri. Maka sesuai dengan realita yang ada, maka ustadz cinta mengambil tema dengan judul Menginstal kasih sayang (memperbaiki). Beauty and the beast, Materi Beauty and the beast terinspirasi dari sebuah film beauty and the beast, yaitu kisah cinta antara si cantik dan si buruk rupa, namun dalam kajian ini adalah lebih pada perubahan diri. Kajian ini diadakan pada tanggal 08 oktober 2017 di Masjid Agung Kota Sukabumi.

Selain itu ada judul menarik lainnya, seperti: My hijrah my advanture, Berhijrah menjadi pribadi yang lebih baik memerlukan perjuangan yang sangat dasyat, harus siap untuk dihina orang, dicaci, bahkan perolok-olok. Maka dalam berhijrah perlu asup siraman rohani, memperbayak pengetahuan. Maka dalam kajian ini, ustadz cinta memberikan motivasi leawat kisah perjuangan rasulullah dan para sahabat. Kajian ini dialaksanakan pada tanggal 24 september 2017, pukul 15:00 WIB, di Masjid Agung Kota Sukabumi. Saatnya berubah (my hijrah my adventure part 2), Materi saatnya berubah adalah lanjutan dari materi my hijrah my adventure. Isi dari kajian ini juga melanjutkan pembahasan selanjutnya yaitu saat diwaktu yang tepat untuk berhijrah. Kajian dilaksanakan pada tanggal 1 oktober 2017, di masjid Agung Kota Sukabumi.

\section{Media Tabligh Ustadz Cinta dalam Kajian Majelis Mahabbah}

Media merupakan segala sesuatu yang dapat digunakan untuk mencapai tujuan tertentu, dengan begitu media tabligh berarti sesuatu yang dapat digunakan untuk tercapainya tujuan tabligh yang telah ditentukan.

Seorang mubaligh dalam menyampaikan ajaran agama islam kepada umat manusia tidak lepas dari media (wasilah) tabligh. Kepandaian memilih media yang tepat dalam bertabligh merupakan salah satu unsur keberhasilan tabligh. Terlebih saat ini perkembagan zaman semakin meningkat dan pesat, yang ditandai langsung 
oleh perkembangan teknologi.

Masyarakat saat ini adalah masyarakat yang berkembang dengan kebutuhan yang serba praktis, sehingga kecanggihan teknologi menjadi alat utama dalam kehidupan masyarakat. Maka dalam memilih dan menggunakan media tabilgh (ceramah) yang tepat merupakan sebuah keharusan dan tuntutan zaman.

Berkaitan dengan media tabligh ini, ustadz cinta sepakat dengan pendapat Ahmad Subandi bahwa Media tabligh berdasarkan jenis dan peralatan yaitu dengan memakai media versi modern, yaitu dengan menggunakan laptop, infokus, layar dan mic. Dengan peralatan seperti ini memudahkan para mubalagh dalam melihat pesan yang disampaikan, lebih praktis dan pesan lebih tersampaikan dengan jelas.

Media yang digunakan Ustadz Cinta dalam bertabligh adalah media yang kekinian, dengan menggunakan laptop, infokus dan layar memudahkan mubalagh untuk melihat pesan yang disampaikan, penyajian materipun bisa berupa poinpoin penting yang dimuat dalam bentuk slide.

Selain itu, beberapa minggu sebelum acara kajian dilaksakan, ustadz cinta mebuat sebuah poster tentang acara kajian, hasilnya langsung disebarkan di berbagai sosial media. Maka pada acara kajian berlangsung dalam menyamapikan isis pesan tabligh ustadz cinta menampilkan pamplet dan power point .

\section{Metode Tabligh Ustadz Cinta dalam Kajian Majelis mahabbah}

Metode merupakan cara atau jalan yang harus dilalui untuk mencapai suatu tujuan. Sehingga ustadz cinta memahami bahwa metode tabligh adalah cara-cara tertentu yang dilakukan oleh seorang mubaligh untuk menyampaikan ajaran islam kepada mubalagh agar mencapai suatu tujuan atas dasar hikmah dan kasih sayang. Dalam menyampaikan pesan tabligh, metode sangat penting peranannya, meskipun pesan itu baik, tapi cara menyampaikannya tidak benar, pesan itu bisa saja tertolak atau tidak diterima oleh mubalagh.

Ustadz cinta sependapat dengan Aep Kusnawan dalam bukunya yang menyebutkan bahwa Metode tabligh berpijak pada tiga aspek yaitu tabligh mimbar (khitobah), kitabah, dan i'lam (radio, tv, film). Dalam penyampaian tablighnya Ustadz Cinta memakai ketiga metode tersebut, pada tabligh kitabah Ustadz Cinta menulis kajian islami pada koran Pikiran Rakyat, sudah berjalan dari mulai tahun 2016 sampai sekarang, untuk di i'lam beliau mengisi kajian di radio ar-royan sukabumi dan di subi tv, sudah di mulai dari 2016 sampai sekarang, untuk ranah khitobah membuka lima kajian yaitu, training motivasi, mahabbah training center, pesantren biru, generasi hijrah cinta, dan majelis mahabbah.

Pada penelitian ini di khususkan pada kajian Majelis Mahabbah yang berada di tabligh khitobah, maka kajian majelis mahabbah memiliki metode yang berbeda dengan kajian yang lain, untuk kajian ini metode yang dipakai adalah metode ceramah, diskusi, dan muhasabah.

Pertama, Ceramah, Metode ceramah merupakan salahsatu metode yang paling banyak digunakan dalam menyampaikan ajaran islam, metode ceramah ini dilakukan dengan menyampaikan materi tentang ajaran islam kepada para 
mubalagh secara langsung atau dengan cara lisan. Penggunaan metode ini sifatnya sangat praktis dan efisien bagi seorang mubaligh dalam menyampaikan materi. Metode ceramah merupakan cara yang paling tradisoanal dalam menyampaikan ajaran islam, oleh karena itu metode ini bisa dikatakan sebagai metode tradisoanal dan mudah untuk dipakai.

Ustadz Cinta dalam menyampaikan kajian mahabbahnya menggunkan metode ceramah, yaitu dengan menyampaikan materi secara langsung kepada para mubalagh yang hadir, metode ini sangat mudah diterima dan mudah dipahami oleh para mubalagh. Dalam pelaksanaannya, Ustadz Cinta menerangkan materi tabligh (ceramah) dibantu dengan menggunakan power point. Setelah itu Ustadz Cinta mengebangkankan point point yang sudah ada dipower point.

Menurut ustadz cinta ada beberapa kelebihan dalam menyampaikan ajaran islam menggunakan metode ini, yaitu sebagai berikut: Mudah untuk mempersiapkan dan mempraktekannya, Lebih tepat sasaran, Dapat membantu para mubalagh agar lebih akurat, kritis dan penuh perhatian dalam mendengarkan isi pesan, Mudah menguasi dan mengkondisikan para mubalagh, Isi pesan tersampaikannya langsung pada para mubalagh, konsep yang digunakan lebih mudah, lebih efektif dalam menyampaikan ajaran islam

Kedua, metode diskusi. Selain menggunakan metode ceramah Ustadz Cinta juga memakai metode diskusi, menurutnya dengan metode ceramah terkadang tidak semua orang dapat memahami langsung, maka dengan alternatif lain yaitu membuka forum diskusi, jadi setelah metode ceramah diterapkan maka selanjutnya dibuka forum diskusi antara mubalagh dengan mubaligh. Dengan menambah metode ini semakin memperkuat dari metode ceramah, sehingga isi pesan yang disampaikan sampai benar-benar dipahami oleh para mubalagh.

Metode diskusi juga sebagai alternatif agar mubalagh tidak mengantuk saat mendengarkan isi pesan tabligh, dengan menggunakan metode diskusi para mubalagh bisa bertanya seputar judul atau diluar judul yang masih belum dimengerti.

Dalam pelaksanaannya metode diskusi dibagi menjadi dua cara yaitu: bertaya secara langsung, bertanya melalui tulisan. berkaitan dengan cara berlasungnya diskusi atau tanya jawab diatas, dapat kita ketahui bahwa setiap orang dalam mental untuk bertanya berbeda-beda, ada yang secara langsung berani bertanya, ada juga yang memang suasah untuk bertanya langsung atau malu untuk mengatakan secara langsung. Maka Ustadz Cinta dalam sesi diskusi ini memakai dua cara.

Ketiga, Metode muhasabah. Metode muhasabah merupakan salah satu metode yang jarang orang gunakan dalam menyampaikan ajaran islam, metode ini biasanya dipakai diacara training motivasi. Tapi untuk ustadz cinta memakain metode ini pada acara pengajian, hal ini sangat menarik perhatian para mubalagh. Dengan metode ini para mubalagh dapat merenungi dan menjadi bahan perbaikan diri untuk pribadi yang lebih baik lagi, sehingga sangat efektif disetiap terakhir penyampaian kajian dengan menggunakan metode muhasabah. 
Metode muhasabah memberikan hasil yang maksimal dipenghujung acara, sehingga para mubalagh bisa mengaplikasikan langsung pesan yang disampaikan oleh ustadz cinta. Metode ini berpengaruh besar dalam melakukan tabligh, karena metode ini lebih pada menyentuh pada hati setiap mubalagh

Respons dari para mubalagh tentang metode muhasabahpun sangat bagus, hasil wawancara dari beberapa para mubalagh menyatakan bahwa, " dengan muhasabah kita bisa sadar diri bahwa diri kita banyak dosanya, belum bisa mencinta apapun karena Allah, dan bisa tersadarkan bahwa setiap hari kita melakuakan dosa, dari hasil muhasabahlah kita bisa melakukan perbaikan diri menajdi diri yang lebih baik, sedikit demi sedikit mulai bisa berubah".

Adapun beberapa kutipan dari isi muhasabah yang beliau ucapakan kepada para mubalagh dipenghujung acara, yaitu sebagai berikut:

"Ya Allah satukanlah kami dalam dakwahMu, berpadu dalam membela syariatMu, maka kokohkanlah ikatan ukhuwah, tetapkanlah cintanya, tunjukilah jalan-ajalannya, hubungilah hati-hatinya. Ya Rabbana, walaupun kami kurang cinta, maka tampakan cinta kami, walaupun kami kurang rindu kepadaMu. Sehingga kami tergolong syadu hubba fillah, tergolong pada orang-orang yang sangat cinta kepadaMu, orang-orang yang amat rindu kepadaMu, orang-orang yang hatinya bergetar saat menyebut namaMu, orang-orang yang bertaqwa ketika mendengar ayat-ayatMu.

Ya Allah dekatkanlah kami yang jauh menjadi sedekat-dekatnya denganMu, terangi kami dari hati yang segelap-gelapnya, lembutkan dari sekeras-kerasnya hati kami untuk merindui dan mencintaiMu." Kata-kata muhasabah yang sangat menyayat hati dan menggetarkan jiwa, sehingga para mubalaghpun ikut meneteskan air mata.

\section{PENUTUP}

Berdasarkan hasil penelitian yang sudah di paparkan di bab III dapat disimpulkan sebagai berikut:

Pertama, konsep tabligh ustadz Cinta dalam kajian mahabbah. Ustadz cinta dalam bertabligh memakai konsep yang bernama nanajemen cinta, konsep ini sama dengan etos kerja berbasis spiritual. Konsep mamajemen cinta merupakan konsep yang menghadirkan dalam setiap programnya dikemas dalam bentuk motivasi dan siraman rohani yang disesuaikan dengan kebutuhan. Programprogram yang diberikan sangat menarik, inspiratif, inovatif, menyentuh hati, dan memberikan ide-ide serta hal baru yang dapat di aplikasikan dalam kehidupan sehari-harikeunikan ustadz cinta dalam bertabligh

Kedua, Metode tabligh, ustadz cinta dalam kajian majelis mahabbah memakai metode yang berbeda dengan kajian yang lain, untuk kajian ini metode yang dipakai adalah metode ceramah, diskusi, dan muhasabah.

Ketiga, Materi tabligh Ustadz Cinta dalam kajian Majelis Mahabbah adalah tentang cinta, bagaimana semua orang bisa memanage cinta agar terarah pada cinta kepada Allah, baik pada sesama manusia, orang tua, terhadap pekerjaan, 
R. Angelia, A. Muhyiddin, \& T. Sukayat

terhadap ibadah, dan yang lainnya.

Keempat, Media tabligh yang dipakai oleh ustadz cinta memakai jenis dan peralatan media versi modern, yaitu dengan menggunakan laptop, infokus, layar dan mic. Dengan peralatan seperti ini memudahkan para mubalagh dalam melihat pesan yang disampaikan, lebih praktis dan pesan lebih tersampaikan dengan jelas.

\section{DAFTAR PUSTAKA}

Ahmad, Warson Munawir. 1997. Al-Munawir Kamus Besar Arab-Indonesia, Surabaya: Penerbit Pustaka Progresip

Aripudin, Acep. 20013. Sosiologi Dakwah, Bandung: Penerbit PT Remaja Rosdakarya

Anshari, Hafi. 1993. pemahaman dan Pengembangan Dakwah, Surabaya: Penerbit AlIkhlas

Anshari, Saepudin Endang. 1991. wawasan islam, Jakarta: Penerbit Rajawali Press Asep, Muhyiddin. Safei, Agus Ahmad. 2002. metode pengembangan dakwah, Bandung Bambang, s. Ma'arif, 2010. komunikasi dakwah, Bandung

Enjang, Aliyudin. 2009. dasar-dasar ilmu dakwah, Bandung: Penerbit Widya Padjadjaran

Echols, John M. 1975. Kamus Inggris Indonesia, jakarta: Penerbit PT Gramedia Pustaka Utama

Ilahi, Wahyu. Hefni, Harjani. 2007. Pengantar Sejarah Dakwah, Penerbit Prenada Media Group

Ibrahim, imam. 1985. Ushul al-ílam al-islamy, Mesir:Kairo: Penerbit Dar al-Fikr alArabiya

Tajiri, Hajir. 2015. Etika dan Estetika Dakwah, Bandung: Penerbit Simbiosa Rekatama Media

Kusnawan, Aep. 2004. komunikasi penyiaran islam, Bandung : Penerbit Benang Merah Press

Muhtadi, Asep Saeful. 2012. Komunikasi Dakwah Teori, Pendekatan, dan Aplikasi, Simbiosa Rekatama Media

Mulyana, Dedi. 2012. ilmu komunikasi suatu pengantar, Bandung: Penerbit PT Remaja Rosda karya

Munadi, Didi Ardin. 2013. Psikologi Dakwah, Bandung

Mulyana, Dedi. 2001. nuansa-nuansakomunikasi, Bandung: Penerbit PT. Remaja Rosdakarya

Muhammad, Sayyid Thanthawi, 2013 Ulumul Qur'an, Jogjakarta: Penerbit Ircisod

Muhammad, Abu Zahrah, Zahrat al-Tafasir, kairo: Penerbit Dar al-Fikr al'Araby,tt,jilid 2

Rakhmat, Jalaludin. 1992. Retorika Modern Pendekatan Praktis, Bandung: Penerbit PT Remaja Rosda Karya

Saputra, Wahidin. 2011. Pengantar ilmu dakwah, Jakarta: Penerbit PT Raja Grapindo Persada 
Sukayat, Tata. 2009. Quantum dakwah, Jakarta: Penerbit PT RINEKA CIPTA

Tim penyusun pusat bahasa, 2008. Kamus Besar Babasa Indonesia, jakarta: Penerbit pusat bahasa 2008

Yakub, Mustofa Ali. 2009. Sejarah dan Metode Dakwah Rasulullah, Pustaka Firdaus Ridwan, A. (2009). Monologika; Retorika untuk tabligh islam (menelusuri sejarah menemukan arah) dalam Ilmu Dakwah: Academic Journal for Homiletic Studies, 4(14), 22. 
R. Angelia, A. Muhyiddin, \& T. Sukayat 